量のベンゼン連日投与の少なくとも初期に注，enzyma tion の機能の低下がおこると䠸えられる。さらにラッ トについての琵験もあわ戊報告する。

304. C.N.B. (P-Chloronitrobenzene) 中壱におけ る赤血球 Heinz 小体について

石渿澄子（算不病理）

体重 $2 \mathrm{~kg}$ 前後の雄性蒙鬼飞少量の P-C.N.B(0.1g） $\mathrm{kg}$ olive 油潋解) 死連続皮下注射すると，第 1 回注射 後には赤血球の 70〜80\% に出現した Heinz 小体（以 下H小体）は，その後，注射を反㠅しているにかかわら ず，10日目前後には 10〜20\%は減少し, 以後, 同様の数 值で消長し, 初期の增加丞示さない。( 6 力月後まで観察)

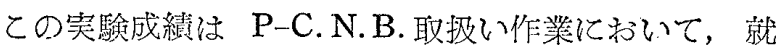

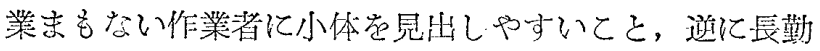

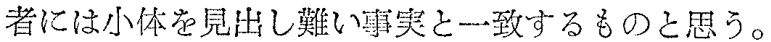

なお，かかるH小体の推移と Met-Hb 暈との関連を 追求守るために，P-C.N.B. $(0.2 \mathrm{~g} / \mathrm{kg}$ clive 油溶解) 学第 1 回注射後，4，6，12，18，24㭙間でこに Met-

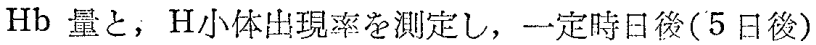
同量の再注射学行ない，同条件で，Met-Hb 最と H 小 体出現状態を観察すると，Met-Hb 量は第 1 回注射捘 とほぼ等量形成されるにかかわらず，H小体の出現のみ 著るしく，抑制されるという成績を得た。

すなわち，第 1 回注射後には 12〜15 㭙間で，H小体 は全赤折球のほほ半数に見出され，24時間後にはほほと んぞ全赤血球に出現するのに比して，第 2 回注射後では 24 30時間で, ようやく半数に達し，以後，増加を示さ ない。

いいがれば，筙 2 回注射後で注H小体の出現恃期も

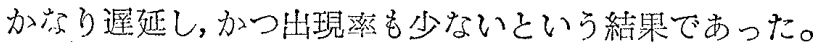

現在, 第 3 回, 第 4 回の注射後の Met-Hb 量, H小 体の消長について，観祭中である。

\section{P-nitrochlorobenzene 中垔に関する実験的研究}

竹村 望，山村行夫，野川仁（慈大・公衛） 石津澄子（挣研病理）

ウサギに P-nitrochlorobenzene (以下 PNCB) 芷 $0.5 \mathrm{~g} \mathrm{~kg}$ 注射して, 中毒をおてきしめた場合のMet-Hb, Heinz 小体の帅成己 Hb-SH の変化について追求した。

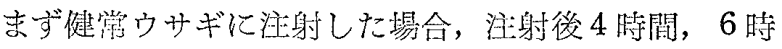

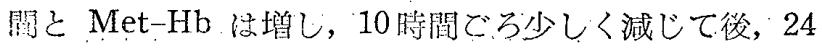

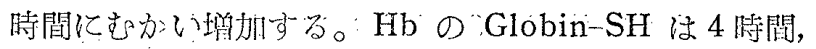
6 時間と減少し，24㭙にむか心い少しく回復するが，との

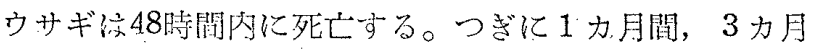

間，および6力月間，3日方に PNCB 崖 $0.1 \mathrm{~g} / \mathrm{kg}$ 注射して慢性投与を行なったそれぞれのウサギ（このよ うな慢性投与では第 2 回目の注射以後ばはんど Met $\mathrm{Hb} や$ Heinz 小体の形成は認められない）に，前と同 様に $0.5 \mathrm{~g} / \mathrm{kg}$ 注射した埸合，1力月間慢性投与のウサ ギでは Met-Hb の堌加も Globin-SH の減少も, はし

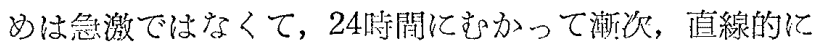
两者逆相関的に変化が進み，これは48時間队に死亡し た。 3 力月間, まよび 6 力月間, 慢性投与党行なったウサ ギでは $0.5 \mathrm{~g} / \mathrm{kg}$ の投与で Met-Hb は 4 時間, 6 時間と 少しく垍加して，10時間ごろ一たん減少し，後，再び増 加するが，48時閻㞾過ぎるともとに復し，Globin-SH の变化もとれと逆相関的に增娍して,やはり48問後に はもとに復し，このように 3 力月間，6力月間の慢性投 与䘮受けたウサギでは，つぎに大量の投与炭行なっても 死亡せず，著るしい耐性学示した。

これらの实験における Met-Hb 师成, Globin-SH の変化に伴って，Heinz 小体の非成崖見るが，てれら の閊の生成機序について, また Met-Hb や Globin-SH の上記の如き二相性の変化の現方れや，慢性投与の两性 の問題などについて考察を行なった。

306. ベンゼン中毒に関する研究 第 2 瞃 ベンゼシ中 青に打ける硫黄化合物の意誐

村上 宏 (京大・公衛)

Duvoir や Raymond 支中心子するフラシス学派法 benzene の代謝過程における phenylsulphate 形成为 体内の硫黄化合物，とくに glutathione の消貿学とも

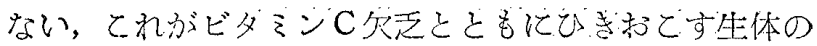

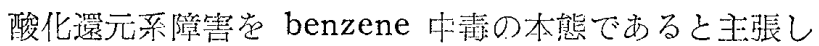
ている。

ての説の当奋学検討する手がかりとして，まずマウス に acetoacetic acid 岩婵日皮下注射して，体内の： glutathione を減少させ，てれによって benzene 中毒 㭙にみられるような血球減少がもたらされるか否かるし らべたととろ，肝藏の glutathione 量の低下と白血球 数の減少は平行していた方，glutathione 量と赤血球 との閵には相関が認められなかった。

また肝臟の glutathione 量と p-nitrophenylsul phate 合成する醉素の活性庭との関係を，マウスにつ いてしらべた結果，ての雨者の間には相関関係が認めら れた。との酵素は西金属によって阻寈されるが，その阻 害は glutathione によって回復する。

そこで,さらに含琉アミノ酸摂取䡒と朋臟中の gluta- 
thione 量との関係，ならびに含硫アミノ睃およびその

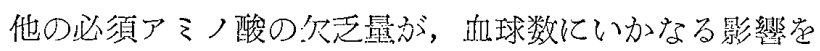
与觉るか觉追求し，栄養状態の良否が，中請発現にごの ような意義をもつがついて检討した。

\section{3ง7． ベンゾール中望時における解琶酵素群活性の变化 についてー-(1)}

$$
\text { 池田正元（京大・公衛） }
$$

Benzol の解埥に関連する酸素群依， benzol より phenol 学生成する群と，むらに phenol より phenylsulfate 芷生成する群とに2大別するとと放できるが， 今回は後者について実験走行なった。

(1) Lipmann らによれば, phenol-sulfokinase は p-nitrophenol に対しても， phenol に詨すると同様 に, 活性を示すとしており，本笑䮲においては，基質とし $て$ p-nitrophenol 色用いた。能势らの方法を一部改良 して処理・定量した家鬼肝 homogenate の900g-10分 冷涷遠沈上清液の活灶值注，ある簌国内で，上清液量预 よび反応時間に大略比例し，同液を用いて肝の p-nit-ro phenyl sulfate 生成能力定定し得るとと莫知った。 この活性值定量により, 肝の phenyl sulfate生成能力, したがって benzol 解毒能力の一端芭うか的い得ると 考光る。

(2) 生後 $9 \sim 10$ 力月の雄・雌性家鬼背部皮下に, benzol $0,5 \mathrm{cc} / \mathrm{kg}$ 隔日在注射し, 第 1 日注射直後, 第 20日，第30日，第40日目に上記(1)の方法により， p-nitrophenyl sulfate生成能力を，またアマランス法によ り，注射後24時間尿のエーテル硫酸比を比め, benzo 1 中責時における解毒能力の变化を追求した。

\section{8. ベンゼン中畵における代謝物の意義について}

吉田克己, 大島秀彦 (三重県大・公衛)

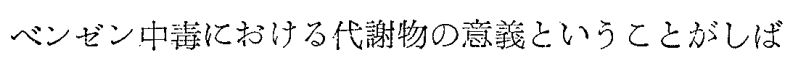
しばいわ礼ているぶ，この間題侍，ベンゼン中毒の具体 的な定義と切り離すとと注で热い。篗者はての点に関 して主として急性毒性の面から，予供的な試み觉行なっ たので，てれを報告する。

志ず，代謝物の中心点の位監を占わるところの phenol のエーテル硫酸茬得るために，てれの合成莫行なっ た。phenol の水素をエーテル型に硫酸エステル化する ためには，ピロ硫酸による方法と，塩基中でクロルスル フォン酸と中和的に縮合せしめるてと方洘元られている が，前者は収量悪く，後者の方がはるかに優れ，多量范 得ることができた。
ついで，マウス使用して，ベンゼンフエノール( $\mathrm{Na}$ 程), 酸性硫酸エステル(K塩)の3者について, 致死量 㘂しらべ,つぎの結果営得た。

ベンゼン : $3.7 \mathrm{~g} / \mathrm{kg}$, フェノール: $0.37 \mathrm{~g} / \mathrm{kg}$, 酸性硫 酸エステル $: 2.2 \mathrm{~g} / \mathrm{kg}$

ベンゼンが曼も表性が低いが，呼気中に失なわれると と花考慮する必要がある。しかしフェノールの高毒性に 此してかなり低い。硫酸エステルはフエノールの誘導体 ではあるが，化学棈造上はほとんど無縁であって，立体 構造汃ら㹥むしろ benzensulfonamide に深縁な别個 の化合物之考えるべきで，投与時の動物の挙動もフエ， 一ルと関係がない。

ベンゼンの生体内代謝がはたして合目的的な解量機構 かと考光ると，上記の如く毒性低下とはほとんど関係が

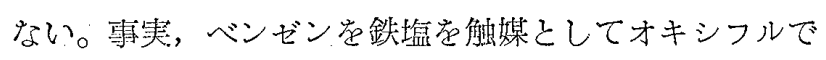
$38 \sim 40^{\circ} \mathrm{C}$ で酸化すると,フエノールとカテコールを生 し，その蚛合も生体内変化ときわわて上く類似してお り，生体内代謝もまた一般的な酸化反応とほとんぎ翼な らないものであって, 酸素反応が関与するにせよ，その 方向と量的関係はほとんぞ同一の酸化反応である。

くわしくは, ベンゼン中毒の意味から考党て, 造血系 老目標として各代謝物について検討すべきであるが，急 性的な結果のみ苍報告する。

\section{Benzol その他の類似害物の急性中毒時の家鬼深} 部脳波所見について

笠投 勉（神戸医大・神経）

川上正澄（神戸医大・生理）

高野秀勝（湊川病院）

従来, 恝物中瑇の身体諸臟器運動系についての研究は 数多くなされているが，中毒と中枢神経系との関係につ

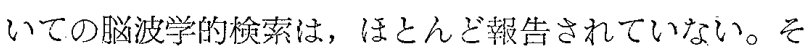
てで我々法工業中毒として注目されている Benzol， Nitrobenzol，Anilin について，とれら毒物の中枢作用 老研究の対象とし，成熟家鬼堂用い，無麻醉，人工呼吸 下で開頭し，定位測定立体装置党用いて，同心電極を脳 内諸所の部位に刺入し，Amelizol 投与による筋運動の 不動化を施しつつ，上記義物の皮質皮質下の電気的活動 におよ仿す影響范，脳波にて記録観察し，つぎの如き成 績觉得た。

これら毒物の中枢作用の共通点として, 視客下部底部 諸核, 扁桃核, 海馬の 3 領域並びに後部辺縁皮質部に, 早期に高頻度の限局性発作波の誘発が認好られている。

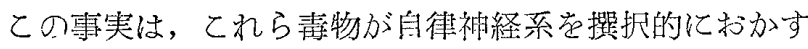

